\title{
Ana Batik Magelang's Business Development Strategy Based on SWOT and Business Model Canvas
}

\author{
Tri Puji Hastutik ${ }^{1)}$, Ivo Novitaningtyas ${ }^{2)^{*}}$ \\ ${ }^{1), 2)}$ Universitas Tidar, Indonesia \\ Email:tripujih599@gmail.com ${ }^{l)}$,ivo.novitaningtyas@untidar.ac.id ${ }^{2}$ \\ ${ }^{*}$ Corresponding author
}

\begin{abstract}
This study aims to analyze Ana Batik's business conditions as one of the MSMEs in Magelang based on the Business Model Canvas (BMC) analysis to develop a business strategy based on a SWOT analysis. The research was developed based on a descriptive qualitative approach. The data used in this study are primary data and secondary data. Primary data were collected through observation and interviews, while secondary data were collected through literature studies. The data that has been collected is analyzed based on the Business Model Canvas (BMC) analysis and the SWOT analysis. The Business Model Canvas (BMC) analysis is used to describe Ana Batik's business conditions, while the SWOT analysis is used to formulate a business development strategy that is applied to the new business model. The results of the data analysis indicate that the appropriate strategy for Ana Batik Magelang's business development is the SO strategy. SO strategies that can be applied are developing products according to fashion trends, using brand ambassadors to attract and increase consumer buying interest, and expand the market to the scope of the global market. By implementing this strategy, it is hoped that Ana Batik Magelang's business can develop and be sustainable.
\end{abstract}

Keywords: Batik MSME, Business Strategy, Business Model Canvas, SWOT

\section{Introduction}

The creative industry is one of the industrial sectors that plays an important role and makes a significant contribution to the Indonesian economy (Mustikarani \& Irwansyah, 2019). This industrial sector does not only function as a driving force for the economy but also as a source of development and livelihood for the people of Indonesia. According to Gumilar (2015) the creative industry is a sector that utilizes the skills, creativity, and talents of each individual so that it can produce innovation by exploiting the creativity and creativity of each individual. The fashion industry is one of the creative industry sectors that has experienced rapid development (Rochani, 2017). The times have influenced the lifestyle of the people in the dress. The majority of people think that the style of dress can be used as a means to communicate and show the lifestyle and identity of the wearer in addition to covering and protecting their bodies. Based on this condition, the fashion industry has the potential to be developed.

Magelang is one of the regions that also develop the fashion industry to support the economy in Indonesia. Various kinds of businesses in the fashion sector developed in Magelang, such as convection (Garment), boutique, fashion distribution, clothing store, and textile shop. However, changes in consumer lifestyles and people's tastes in Magelang, which currently tend to choose online shopping, have an impact on the ability of fashion entrepreneurs in Magelang to be able to adapt to increasingly rapid technological developments. Based on research conducted by Litbang Borobudurnews, nearly 30 percent of shops in the Magelang area were forced to close and some of them are fashion shops. This occurs due to the inability of entrepreneurs to adapt 
and update their business strategies.

Ana Batik is one of the fashion industries in Magelang. Ana Batik is engaged in the home industry or production house and retail. Ana Batik started her business by setting up a retail store in 2006 and then establishing a production house in 2018. The production house in addition to producing clothes to be marketed in retail stores, also produces clothes with a made by order system according to customer needs. Rapid technological advances and increasingly competitive business competition have encouraged Ana Batik to continue to strive so that it can survive and continue to grow. Based on this, it is necessary to identify Ana Batik's current business conditions to determine the next business development strategy.

Identification of current business conditions consists of how the product and development potential product, how many set price, who is the distribution channel, and how promotion is done (Kotler \& Keller, 2018). The business model canvas is an analysis tool to see the conditions of a business and provide an overview of the next business plan. Based on this analysis, entrepreneurs can see the development of their business conditions through mapping on a canvas (Novitaningtyas, Achsa, \& Rahardjo, 2020). Elements of the business model canvas, such as customer segment, value proposition, channel, customer relationship, revenue stream, key resources, key activity, key partnership, and cost structure (Koswaraputra, Sinaga, \& Andati, 2019; Rahardjo, Hasbullah, \& Taqi, 2019). Previous researchers have used BMC analysis to map the conditions of the fashion business (Narto, 2017; Priyono, 2015). However, similar research has not been done on the batik fashion business in the Magelang area.

Moreover, in developing a business development strategy, a SWOT analysis is needed to identify the strengths, weaknesses, opportunities, and threats faced by the business. SWOT analysis is an analysis tool used to identify and analyze the company's internal factors including strengths and weaknesses as well as external factors including opportunities and threats (Andrian, 2019). The results of the identification and analysis of internal and external factors can be used to formulate the right strategy by transforming the potential that is owned into an effective strength. Thus, the organization, business, or company can have a reliable competitive advantage. SWOT analysis used to identify the internal and external environmental conditions of a business can also be applied by Ana Batik to develop a business model and formulate the right strategy.

Based on the description previously explained, further research is needed to analyze the business conditions of Ana Batik Magelang based on BMC analysis. Furthermore, a SWOT analysis is carried out to formulate a strategy to develop Ana Batik's business. Thus, the research results can provide benefits for Ana Batik to develop her business. In addition, the research results are also useful as a reference source for further research in formulating business strategies for fashion MSMEs.

\section{Literature Review}

\subsection{Business Model Canvas}

Business Model Canvas (BMC) is a strategic tool to describe a business model and describe the concept of an organization's thinking (Koswaraputra et al., 2019). BMC is also used to make business concepts simpler and displayed on canvas sheets. The canvas sheet contains a business plan based on 9 key elements which include an analysis of the company's internal and external strategies. BMC consists of 9 elements, namely (1) Customer Segment, (2) Value Proposition, (3) Channel, (4) Customer Relationship, (5) Revenue Stream, (6) Key Resources, (7) Key 
Activity, (8) Key Partnership, and (9) Cost Structure (Rahardjo et al., 2019).

\subsection{SWOT Analysis}

According to Rusliati et al., (2018), SWOT analysis is a method used to analyze and identify the company's internal environment including Strengths and Weaknesses, as well as the external environment including Opportunities and Threats. The results of the analysis and identification of the internal and external environment are used by the company to formulate the right strategy to facilitate the company in achieving its goals. According to Ezizwita \& Sukma (2021), SWOT analysis is an approach that tries to balance the strengths and weaknesses of the organization's internal environment with the opportunities and threats of the organization's external environment. SWOT analysis can be used to help analyze strategies with logical references and a systematic discussion of the condition of the organization or company. Thus, strategic alternatives are obtained as the basis for making organizational or company decisions.

\section{Research Method}

The research was conducted at Ana Batik Magelang for 3 months, from February to May 2021. The types of data used in this study were primary data and secondary data. Primary data obtained based on interview and observation methods. Interviews were conducted with business owners, managers, and employees. While secondary data is obtained from literature such as journals, sales reports, and data from Ana Batik, as well as books. This study used a descriptive qualitative approach where BMC and SWOT analysis were used to describe the business conditions and the formulation of Ana Batik's business strategies. The research flow framework can be seen in Figure 1.

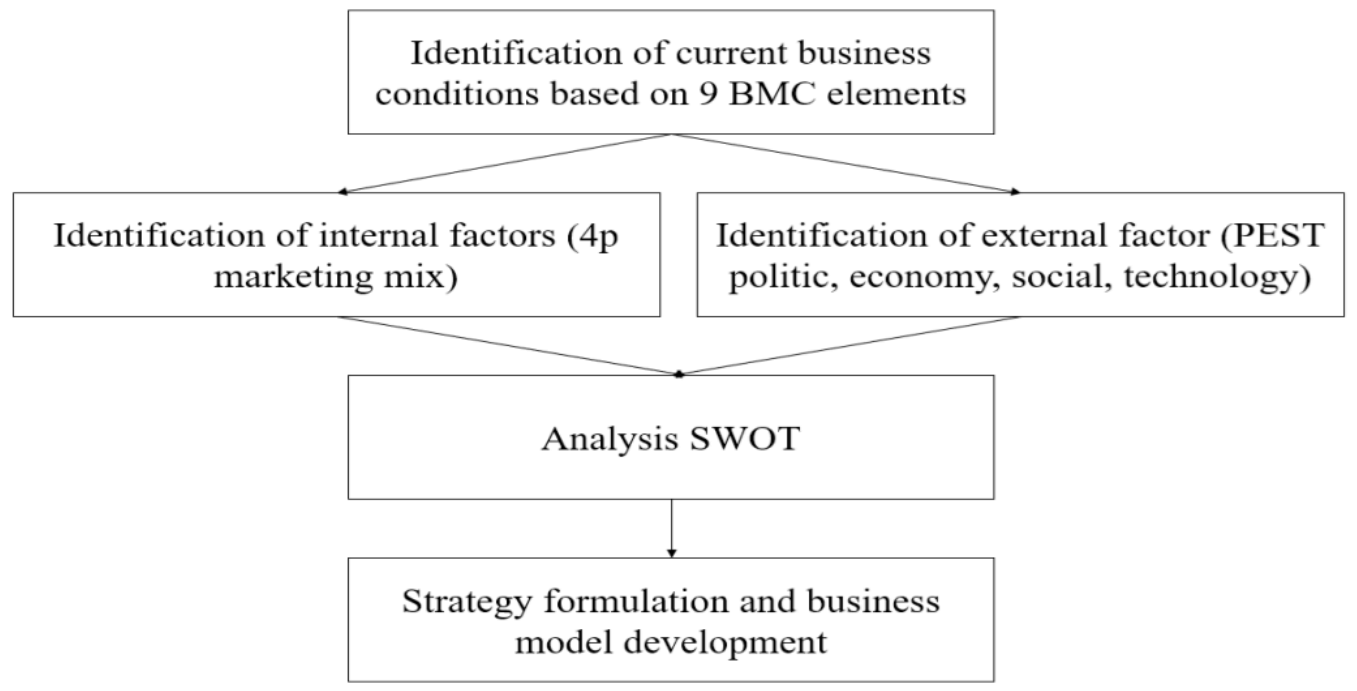

Figure 1. Research Framework

\section{Findings and Discussions}

\subsection{Ana Batik's Current Business Condition}

Ana Batik is one of the creative industries in the fashion sector in the Magelang area. Its production house is located at Jalan Sawo, Japunan, Danurejo, Magelang. The retail stores are located at Pasar Rejowinangun Kios Number 613 and the Valencia Magelang shophouse on the first floor. Ana Batik has 13 employees. Ana Batik provides the best service to customers by 
offering products made based on orders from customers (Make to order), customers can make designs or clothing designs according to customer wishes (Design to order), and products are made based on Ana Batik's provisions before accepting orders as supplies. As well as for sale at Ana Batik retail shop (Make to stock), so customers can buy without waiting for the product to be made or produced. The quality of the materials used by Ana Batik uses the best quality. In addition, the price offered tends to match the quality of the product. Furthermore, Ana Batik also guarantees product repairs ordered through the make-to-order system. For orders with long distances, Ana Batik uses a delivery service that is tailored to the wishes of the customer. Ana Batik also collaborates with the Magelang Job Training Institute (LPK) as a labor supplier, batik craftsmen as suppliers, and resellers as distribution channels.

The following is an identification result of Ana Batik's current business conditions based on the 9 elements of the Business Model Canvas (BMC), detail on Figure 2:

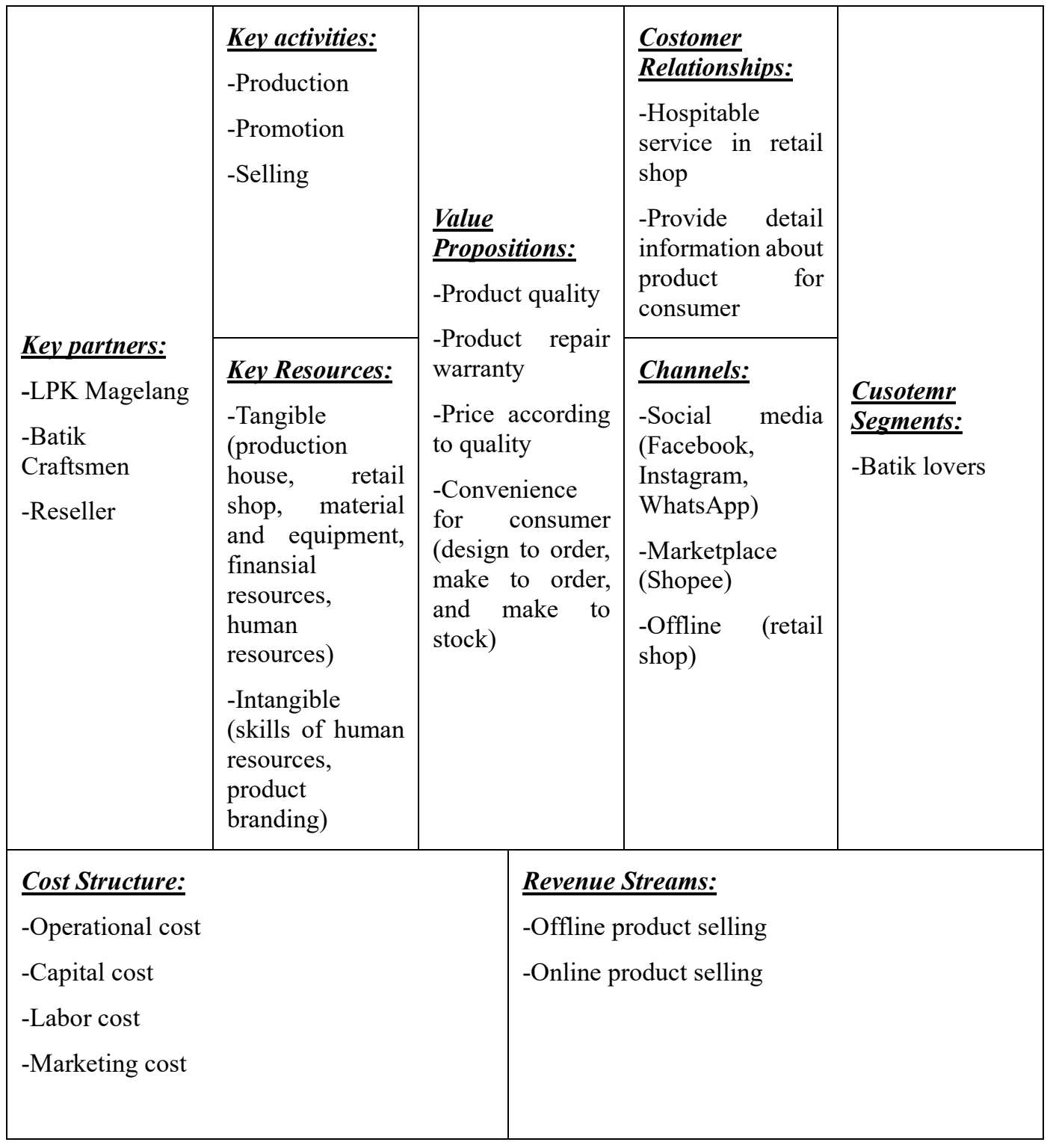

Figure 2. Ana Batik's Current Business Model Canvas

Value Propositions: the values given by Ana Batik to customers are the best quality of raw 
materials, guaranteeing repairs to customers, and providing competitive prices with prices according to product quality. In addition, Ana Batik also provides flexibility for customers with a production system, namely products are made based on orders from customers (Make to order), customers can make designs or clothing designs according to customer wishes (Design to order), and products are made based on Ana Batik's provisions before receiving. orders as inventory as well as for sale at Ana Batik retail store (Make to stock).

Customer Segments: the customer segment of Ana Batik includes all circles of society, especially batik lovers. So far, Ana Batik's customers have spread widely to West Nusa Teggara, East Nusa Tenggara, Kalimantan, and Riau.

Customer Relationship: Ana Batik builds relationships with customers through social media, marketplaces, and meets directly with customers. In addition, the existence of retail stores and production houses can make it easier for Ana Batik to provide friendly service to every customer who comes. Ana Batik can also provide information related to products and receive suggestions and input from customers directly.

Channels: in distributing its products, Ana Batik uses social media such as Facebook, Instagram, WhatsApp, and marketplaces such as shopee. By utilizing this digital platform, Ana Batik can promote products to customers very easily. As for the retail store, which is also a product distribution channel, it can make it easier for customers who want to see Ana Batik's collections firsthand by visiting a retail store or directly visiting Ana Batik's production house.

Revenue Streams: Ana Batik's income comes from selling products online and offline which include shirts, robes, children's clothes, negligee, family uniforms, office uniform, school uniform, and uniforms for certain events.

Key Activities: the key activities carried out by Ana Batik are production, promotion, and sales activities. These activities are activities that are of particular concern to an entrepreneur, especially Ana Batik, to market products to customers.

Key Resources: resources are divided into tangible and intangible. Tangible category resources consist of production houses, retail shop buildings, equipment for making products, materials for making products, capital or financial resources, and human resources as producers of products. The intangible category resources consist of the skills of employees in batik and product branding.

Key Partnership: Ana Batik collaborates with several women, such as the Magelang Job Training Institute (LPK), Batik Craftsmen, and Resellers. This private institution (LPK) acts as a supplier of previously trained workers. Batik craftsmen act as a supplier or supplier of raw materials in the form of batik cloth. In addition, Ana Batik also works with resellers to expand market share and build new customer loyalty.

Cost Structure: in running its business, Ana Batik requires costs to carry out all activities including operational costs, labor costs, capital costs, and marketing costs. Operational costs are used to carry out Ana Batik's daily activities. Labor costs are used as reciprocal because Ana Batik uses human resources to run its business. Moreover, capital costs are very important costs to support Ana Batik's business continuity.

\subsection{SWOT Analysis}

SWOT analysis is used to analyze internal and external factors of Ana Batik. Internal factors consist of strengths and weaknesess related to Ana Batik's business conditions. And external

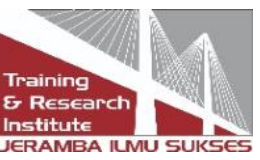


factors consist of opportunities and threats which are analyzed based on economic, political, social, environmental, and technological (PEST) conditions. The SWOT matrix describes various alternative strategies that Ana Batik can do based on the results of the SWOT analysis. The purpose of the SWOT matrix is to develop an alternative strategy that supports a development strategy that is suitable for Ana Batik's conditions. There are four alternative strategies in the SWOT matrix, such as the SO, WO, ST, and WT strategies which are formed by maximizing strengths and opportunities and minimizing weaknesses and threats. The following is an explanation regarding internal and external factors.

\begin{tabular}{|c|c|c|}
\hline External Factor & $\begin{array}{l}\text { Stenghts (S) } \\
\text { 1. Product quality, raw materials } \\
\text { that are superior to } \\
\text { competitors } \\
\text { 2. In collaboration with LPK } \\
\text { Magelang, Batik craftsmen, } \\
\text { and resellers } \\
\text { 3. Having social media account } \\
\text { and marketplace as media for } \\
\text { sales and promotion } \\
\text { 4. Renewal of design and motifs } \\
\text { of products } \\
\text { 5. Have a competitive prices but } \\
\text { affordable }\end{array}$ & $\begin{array}{l}\text { Weaknesess (W) } \\
\text { 1. The use of digital platforms is } \\
\text { not optimal } \\
\text { 2. Human resources do not have } \\
\text { skills in the field of digital } \\
\text { marketing } \\
\text { 3. Lack of facilities that support } \\
\text { the production process }\end{array}$ \\
\hline $\begin{array}{l}\text { Opportunities (O) } \\
\text { 1. The development of cinsumer } \\
\text { fashion needs } \\
\text { 2. The development of digital } \\
\text { marketing } \\
\text { 3. Government support through } \\
\text { Magelang Dekranasda which } \\
\text { encourages creative and } \\
\text { innovative MSME actors } \\
\text { 4. Potential development of the } \\
\text { batik industry globally }\end{array}$ & $\begin{array}{l}\text { SO Strategy } \\
\text { 1. Develop product and product } \\
\text { design in accordance with } \\
\text { emerging fashion trends } \\
\text { (S1,S4\&O1) } \\
\text { 2. Using brand ambassadors to } \\
\text { attract consumer buying } \\
\text { interest (S3\&O2) } \\
\text { 3. Expanding market share to } \\
\text { global markets (S1,S4\&O4) }\end{array}$ & $\begin{array}{l}\text { WO Strategy } \\
\begin{array}{l}\text { 1. } \\
\text { Training and development } \\
\text { skill for human resources } \\
\text { related to digital marketing } \\
\text { (W2\&O3) }\end{array} \\
\text { 2. } \begin{array}{l}\text { Maximizing the use of digital } \\
\text { platforms as promotional } \\
\text { media, expanding market } \\
\text { share, and building brand } \\
\text { image (W1\&O2) }\end{array}\end{array}$ \\
\hline $\begin{array}{l}\text { Threats }(\mathbf{T}) \\
\text { 1. The emergence of similar new } \\
\text { competitors } \\
\text { 2. Low priced competitor } \\
\text { products with the same motive } \\
\text { 3. Environmental conditions and } \\
\text { natural disasters (Covid-19 } \\
\text { pandemic) }\end{array}$ & $\begin{array}{l}\text { ST Strategy } \\
\text { 1. Creating product competitive } \\
\text { advantage (S1,S4,S5\&T1) } \\
\text { 2. Maintain product quality and } \\
\text { raw materials that are superior } \\
\text { to competitors to crate a brand } \\
\text { image and increase customer } \\
\text { loyalty (S1\&T2) }\end{array}$ & $\begin{array}{l}\text { WT Strategy } \\
\text { 1. Increase human resources and } \\
\text { maximize online marketing if } \\
\text { environmental conditions do } \\
\text { not support direct marketing } \\
\text { (W1,W2\&T3) }\end{array}$ \\
\hline
\end{tabular}

Figure 3. SWOT Analysis

Strenghts: in running its business, Ana Batik has several strengths including product quality and 
raw materials that are superior to competitors. As for the design and motive reforms carried out by Ana Batik in order to differentiate between Ana Batik products and competitors' products. Ana Batik also collaborates with the Magelang Job Training Institute and the Ana Batik production house is used as an apprenticeship for LPK participants. This can be Ana Batik's strength because they can see the abilities of the apprentices and when the apprentices have the skills that are needed, Ana Batik can recruit these participants as Ana Batik employees. In addition, Ana Batik also collaborates with batik craftsmen as a supplier who can provide fabric with good quality and motifs, and works with resellers as distribution channels. In marketing and promotion, Ana Batik has taken advantage of advances in technology and the internet by using several digital platforms.

Weaknesses: Ana Batik has some weaknesses, such as not maximizing the use of digital platforms as a marketing medium. Because Ana Batik does not yet have human resources who have skills in the field of digital marketing, so the owner of Ana Batik is still in the hands of the owner of the digital platform. In addition, Ana Batik also lacks human resources with fast sewing skills or professional tailors due to production demands. And the lack of facilities that support the production process, such as highspeed sewing machines, because the electricity voltage at Ana Batik's production house is still low.

Opportunities: opportunities are one of the external factors that can be used to maximize strengths and minimize shortages. Ana Batik can take advantage of the existing opportunities, such as the community's dress style that follows the developing fashion trends, which can be used as a reference for Ana Batik to make designs according to fashion trends. In addition, the rapid development of the digital world can encourage the use of digital marketing as a medium for the promotion and marketing of Ana Batik products. There is an opportunity from the government sector, namely Government support through the City of Magelang Dekranasda which encourages MSME players to be creative and innovative. The development of the batik industry which has been globalized and the batik cloth which is mostly in demand by foreign tourists can be an opportunity for Ana Batik to enter the global market.

Threats: the threat from the external environment of a business is something that must be considered and avoided. The emergence of similar new competitors is a threat to Ana Batik due to the increasingly rapid development of the fashion industry and digital world. In addition, the increasingly competitive business competition in the fashion industry has encouraged new businesses to offer products with the same motive but at a lower price than the price of Ana Batik's products. This can be a threat to Ana Batik because customers will tend to choose products with the same motive and cheaper prices without first looking at the quality of the product. There are threats that occur due to environmental conditions and natural disasters that do not support Ana Batik's marketing activities. Like the Covid-19 pandemic which hit almost all over the world in early 2020, is a condition that threatens the global economy, including the economy in Indonesia. The impact of the covid-19 pandemic caused a decrease in sales of Ana Batik products in retail stores, due to a government policy that prohibits trading activities as a form of preventing the spread of covid-19 in the market environment.

From the SWOT matrix in Figure 3, four alternative strategies are generated as strategic recommendations that can be used by Ana Batik. Based on Ana Batik's internal and external conditions, it can be seen that this business has strengths that can be used to develop the business by taking advantage of the opportunities it has. However, in its application, Ana Batik did not maximize its strength by taking advantage of existing opportunities. Based on these conditions, 
the right strategy to be applied to develop Ana Batik's business is the SO strategy. The SO strategy consists of (1) Developing products and product designs in accordance with emerging fashion trends, (2) Using brand ambassadors to attract consumer buying interest and (3) Expanding market share to the global market.

Based on identification using the Business Model Canvas, it shows that the customer segment of Ana Batik includes all circles of society, especially batik lovers. The rapid development of the fashion industry encourages people's dress styles to keep up with growing fashion trends. So, Ana Batik needs to carry out product development and product design in accordance with the developing fashion trends. As for the products that Ana Batik can produce in product development, such as batik mukena and batik shirts. In addition, the rapid development of digital marketing can be used by Ana Batik to maximize the use of the digital platform as a marketing and promotion medium. Ana Batik can also work with brand ambassadors to attract consumer buying interest through digital platforms. It is hoped that this will influence customer perceptions and be able to build brand image and brand awareness of Ana Batik products. Ana Batik can develop the market by expanding its market share to the global market, because currently batik, which is a cultural heritage of the Indonesian nation, has gone global and is able to attract foreign tourists to batik products in Indonesia. In this case, the resources and production facilities of Ana Batik need to be increased and added to support product development and market development.

\subsection{Ana Batik's Business Strategy Development}

Based on the strategic recommendations from the results of the SWOT analysis adjusted to the Business Model Canvas, a new business model can be formed to develop Ana Batik's business. It can be seen in Figure 4 that there is a development of the Ana Batik Canvas Business Model.

\begin{tabular}{|c|c|c|c|c|}
\hline $\begin{array}{l}\text { Key partners: } \\
\text {-LPK Magelang } \\
\text {-Batik } \\
\text { Craftsmen } \\
\text {-Reseller } \\
\text {-Brand } \\
\underline{\text { ambassador }} \\
\underline{\text {-School or }}\end{array}$ & $\begin{array}{l}\text { Kevactivities: } \\
\text {-Production } \\
\text {-Promotion } \\
\text {-Selling } \\
\text {-Product } \\
\underline{\text { development }} \\
\underline{\text {-Equipment and }} \\
\underline{\text { facilities }} \\
\underline{\text { maintenance }}\end{array}$ & $\begin{array}{l}\text { Value } \\
\underline{\text { Propositions: }} \\
\text {-Product } \\
\text { quality } \\
\text {-Product repair } \\
\text { warranty } \\
\text {-Price } \\
\text { according to } \\
\text { quality } \\
\text {-Convenience } \\
\text { for consumer } \\
\text { (design to order, } \\
\text { make to order, } \\
\text { and make to } \\
\text { stock) }\end{array}$ & $\begin{array}{l}\text { Channels: } \\
\text {-Social media } \\
\text { (Facebook, } \\
\text { Instagram, } \\
\text { WhatsApp) } \\
\text {-Marketplace } \\
\text { (Shopee, } \\
\text { Bukalapak, } \\
\text { Tokopedia) } \\
\text {-Offline (retail }\end{array}$ & $\begin{array}{l}\frac{\text { Cusotemr }}{\text { Segments: }} \\
\text {-Batik lovers } \\
\text {-Children } \\
\text {-Teenage } \\
\text {-Adults } \\
\text {-Foreign } \\
\underline{\text { international }} \underline{\text { tourists }}\end{array}$ \\
\hline
\end{tabular}




\begin{tabular}{|l|l|l|l|}
\hline & $\begin{array}{l}\text { digital marketing } \\
\text {-Intangible } \\
\text { (skills of human } \\
\text { resources, } \\
\text { product } \\
\text { branding) }\end{array}$ & $\begin{array}{l}\text { shop) } \\
\text {-Exhibition } \\
\text {-Website }\end{array}$ & \\
\hline \begin{tabular}{l} 
Cost Structure: \\
-Operational cost \\
-Capital cost \\
-Labor cost \\
-Marketing cost \\
-Development cost \\
-Maintenance cost \\
\hline
\end{tabular}$\quad \begin{array}{l}\text { Revenue Streams: } \\
\text {-Offline product selling } \\
\text {-Online product selling }\end{array}$ \\
\hline Note: underline (create), bold (increase and develop) \\
\hline
\end{tabular}

Figure 4. Development of Ana Batik's Business Model Canvas

Value Propositions: in this value proportion, there is no need to add specifically to Ana Batik's business. However, in running its business Ana Batik still has to maintain product quality and develop products and product designs according to fashion trends. So that customers will be interested in Ana Batik's products because they are different from competitors' products. It is supported by previous study that explained if product quality give a positive impact on consumer purchase decision (Fianto, 2020).

Customer Segments: the customer segment of Ana Batik includes all circles of society, especially batik lovers. This customer segment can be further specified into customers with categories of children, adolescents, and adults. Customer segment development also needs to be done by adding customer segments, namely foreign tourists. This is done because of the high interest of foreign tourists in Indonesia's cultural heritage, namely batik. So, this development will be able to encourage Ana Batik to enter the global market.

Customer Relationship: to improve services and relationships with customers, Ana Batik needs to maximize the use of digital platforms. By always being responsive in providing information and suggestions through digital platforms as well as receiving input from customers and fixing existing deficiencies so that customers will feel satisfied.

Channels: Ana Batik can add distribution channels to increase product sales while expanding market share. Like the addition of a marketplace by adding Bukalapak and Tokopedia to increase the number of Ana Batik customers. It is in accordance with the study from previous researchers that explained if consumer intention buying is increase via market place (Nabilaturrahmah, Wiranata, \& Ivona, 2021; Salsyabila, Pradipta, \& Kusnanto, 2021). The addition of a website for Ana Batik also needs to be done to reach further target markets, improve service to customers because various information related to Ana Batik's products can be accessed easily by customers, and can increase Ana Batik's credibility. In addition, bazaars 
and exhibitions can be added as Ana Batik distribution channels which can be used as promotional media directly to customers, increase brand image, as well as an opportunity for Ana Batik to see competitors and the development of the fashion industry.

Revenue Streams: the development that Ana Batik can do to increase revenue is by using paid advertising platforms such as FB Ads to Adsense or Instagram Ads. Even though the advertising platform is not free, if Ana Batik is able to manage it well, it is hoped that it will be able to get more benefits from Adsense and be able to expand market reach. The addition of products such as batik mukena and batik shirts can increase sales and revenue. Because the majority of Indonesians are Muslim, producing mukena with batik motifs will attract Muslim women in Indonesia to buy. In addition, the addition of batik t-shirts can attract teenagers and foreign tourists who tend to like wearing t-shirts as well as preserving the nation's cultural heritage when many foreign tourists wear batik shirts.

Key Activities: the development of activities at Ana Batik includes additions to the development and maintenance activities of the facility. Development activities are more focused on internal business development, such as developing Ana Batik's HR skills. Meanwhile, facility maintenance activities are carried out to ensure that the facilities for the production process can be used properly.

Key Resources: to maximize Ana Batik's key activities, it is necessary to add more human resources in the fields of digital marketing, administration and finance. Additions to the field of digital marketing need to be done because technological advances are developing very rapidly. In the administrative field, Ana Batik is required to plan, compile, organize, and report related to all Ana Batik activities. As for the financial sector, it needs to be added to regulate everything related to finance in Ana Batik's business. so that the owner of Ana Batik can focus on making decisions and supervising all existing activities.

Key Partnership: Ana Batik needs to work with brand ambassadors and schools or institutions to develop their business. Brand ambassadors can help Ana Batik promote products to customers as well as build a brand image. It can also be used to change customer perceptions so that customers can be interested in buying Ana Batik products. The collaboration between Ana Batik and schools or institutions by accepting apprentices, especially schools or institutions that have major in fashion, can help Ana Batik find employees with good skills.

Cost Structure: with the addition of the addition of the previous elements to develop the business, of course, requires an additional cost structure. The additional costs include marketing costs, development costs and maintenance and maintenance costs. Marketing costs arise because of the addition of the media used for promotion to market products. Development costs are needed to assist in the business development process, such as those related to HR skills development. Meanwhile, maintenance and maintenance costs really need to be added to repair and maintain production facilities so that they can be used properly during the production process.

\section{Conclusion}

Analysis of internal and external factors based on SWOT produces SO strategy recommendations that can be implemented by Ana Batik. The strategy is then adjusted to the Business Model Canvas, thus forming a new business model with developments and enhancements in several elements of the previous business model. The development of some of these elements includes the addition of key activities, such as the development and 
maintenance of facilities supported by key resources which are human resources in the fields of digital marketing, administration, and finance. This is able to increase channels such as adding promotion and distribution channels (Bukalapak, Tokopedia, Website, Bazaar, and Exhibition), as well as developing key partners through collaboration with brand ambassadors and schools or institutions. Thus, it is able to expand the customer segment which must be balanced with the development of a value proposition and an increase in customer relationships. Doing business development, of course, can increase the cost structure, so it is necessary to develop revenue streams to increase revenue that can be used to meet every activity cost in the business. By implementing this new business model, it can help develop Ana Batik's production houses and retail stores as well as the fashion industry in Magelang City. It is hoped that the recommendations for the new strategy and business model will provide benefits for Ana Batik in developing its business. The advice that can be given to Ana Batik is to maximize the use of the digital platform as a promotional medium as well as to expand market reach. In addition, the development of human resources and facilities that support the production process needs to be increased in order to support product development.

\section{References}

Andrian, D. (2019). Analisis SWOT Dalam Menentukan Perumusan Strategi Pada Perusahaan Screamous Malang. Universitas Brawijaya.

Ezizwita, E., \& Sukma, T. (2021). Dampak Pandemi Covid-19 Terhadap Bisnis Kuliner Dan Strategi Beradaptasi di Era New Normal. Jurnal Ekonomi Dan Bisnis Dharma Andalas, 23(1), 51-63. https://doi.org/10.47233/jebd.v23i1.169

Fianto, A. Y. A. (2020). The Antecedents of Purchase Decision for Hijab Fashion Products. Manajemen, 12(1), 154-165.

Gumilar, G. (2015). Pemanfaatan Instagram Sebagai Sarana Promosi Oleh Pengelola Industri Kreatif Fashion di Kota Bandung. Jurnal Ilmi Politik Dan Komunikasi, 2, 77-84.

Koswaraputra, D. I., Sinaga, B. M., \& Andati, T. (2019). Pengembangan Bisnis Media The Jakarta Post Digital. Jurnal Aplikasi Bisnis Dan Manajemen, 5(2), 177-186. https://doi.org/10.17358/jabm.5.2.177

Kotler, P., \& Keller, K. L. (2018). Manajemen Pemasaran Edisi Kedua Belas Jilid 1 (12th ed.). Jakarta: Indeks.

Mustikarani, T., \& Irwansyah, I. (2019). Pemanfaatan Teknologi Informasi dan Komunikasi dalam Industri Fashion Indonesia. Warta ISKI, 2(1), 8-18. https://doi.org/doi: 10.25008/wartaiski.v2i01.23

Nabilaturrahmah, A., Wiranata, I. A., \& Ivona, L. (2021). Pengaruh harga dan promosi grabfood terhadap keputusan pembelian kfc grand wisata di masa pandemi. Manajemen, 13(1), 72-80.

Narto. (2017). Pengembangan Bisnis Model Kanvas untuk Meningkatkan Daya Saing Industri Batik Sumenep Madura. Prosiding Seminar Nasional \& Internasional, 207-215.

Novitaningtyas, I., Achsa, A., \& Rahardjo, B. (2020). Strategi Pemasaran Desa Brajan Menuju Desa Wisata Mandiri. Jurnal Aplikasi Bisnis Dan Manajemen, 6(3), 591-601. https://doi.org/10.17358/jabm.6.3.591

Priyono, F. (2015). Analisa Penerapan Business Model Canvas Pada Toko Moi Collection. Agora, 3(1), 358-363. 
Rahardjo, B., Hasbullah, R., \& Taqi, F. M. (2019). Coffee Shop Business Model Analysis. Integrated Journal of Business and Economics, 140. https://doi.org/10.33019/ijbe.v3i2.153

Rochani, A. (2017). Strategi Pengembangan Industri Kreatif Dalam Mewujudkan Kota Cerdas. Inovasi Dalam Pengembangan, 81-93.

Rusliati, E., Mulyaningrum, M., \& Sufyani, M. A. (2018). Development Strategies of Micro Business in Majalengka Regency. Trikonomika, 17(2), 101. https://doi.org/10.23969/trikonomika.v17i2.1050

Salsyabila, S. R., Pradipta, A. R., \& Kusnanto, D. (2021). Pengaruh promosi dan kualitas pelayanan terhadap minat beli pada marketplace shopee. Manajemen, 13(1), 37-46. 